\title{
EFFECT OF MICROWAVE HEATING ON THE YIELD AND QUALITY OF RED BELL PEPPER PUREE
}

\author{
Hamza Bozkir ${ }^{1, *}$, Ahsen Rayman Ergun ${ }^{2}$, Özge Taştan ${ }^{2}$, Taner Baysal ${ }^{2}$ \\ ${ }^{1}$ Food Engineering Department, Faculty of Engineering, Munzur University, Tunceli, Turkey \\ ${ }^{2}$ Food Engineering Department, Engineering of Faculty, Ege University, Bornova, Izmir, Turkey
}

Received / Geliş: 20.11.2017; Accepted / Kabul: 14.02.2018; Published online / Online bask1: 08.03.2018

Bozkır, H., Rayman Ergun, A., Taştan, Ö., Baysal, T. (2018). The effect of microwave heating on the yield and quality of red bell pepper puree. GID $A$ (2018) 43 (2): 303-312 doi: 10.15237/gida.GD17103

\begin{abstract}
In this study, microwave heating was applied as an alternative method to conventional heating for comparing the effect on the yield and quality of red bell pepper puree. The microwave application was optimized concerning the yield and the outlet temperature by response surface methodology (RSM). The optimum conditions were found to be a power of $900 \mathrm{~W}$ and a flow rate of $6.52 \mathrm{rpm}$ for the microwave oven with RSM. Production of red bell pepper puree was carried out using these optimum conditions. At this optimum point, yield and outlet temperature were found as $76.76 \%$ and $95^{\circ} \mathrm{C}$, respectively. Conventional heating $(\mathrm{CH})$ was performed reaching the same temperature as with microwave heating $(\mathrm{MWH})$ at $95^{\circ} \mathrm{C}$ and a process time of $9 \mathrm{~min}$. As a result, the yield increased by $8.07 \%$ and also the pectin content $(17.75 \%)$ and vitamin C $(20.6 \%)$ were improved by the MWH.
\end{abstract}

Keywords: Red pepper puree, microwave heating, conventional heating, yield, and quality.

\section{KIRMIZI BİBER PÜRESINIIN VERİM VE KALİTESİNE MIKKRODALGA ISITMANIN ETKISİ}

\section{ÖZ}

Bu çalışmada kırmızı biber püresinin verim ve kalitesi üzerine konvansiyonel ssıtma tekniğine alternatif olarak mikrodalga ısıtma tekniği uygulanmıştır. Mikrodalga 1sıtma uygulaması verim ve çıkış sıcaklığı cevap olacak şekilde yanıt yüzey metodu ile optimize edilmiştir. Mikrodalga 1sıtma uygulamasının yanıt yüzey metodu ile optimum koşulları $900 \mathrm{~W}$ güç ve $6.52 \mathrm{rpm}$ akış hızı olarak saptanmıştır. Bu optimum çalışma koşullarında verim ve çıkış sıcaklığ $1 \% 76.76$ ve $95^{\circ} \mathrm{C}$ olarak bulunmuştur. Konvansiyonel ısıtma uygulaması da mikrodalga 1sıtmada ulaşılan aynı sıcaklık derecesinde $95^{\circ} \mathrm{C}$ ve $9 \mathrm{dk}$ olarak yürütülmüştür. Sonuç olarak mikrodalga 1sıtma uygulaması ile verimde $\% 8.07$, pektin içeriğinde $\% 17.75$, C vitamin içeriğinde \%20.6 artış saptanmıştır.

Anahtar kelimeler: Kırmızıbiber püresi, mikrodalga 1sıtma, konvansiyonel 1sıtma, verim, kalite.

${ }^{*}$ Corresponding author / Yazışmalardan sorumlu yazar 


\section{INTRODUCTION}

Pepper, specifically Capsicum annum, used as vegetable and spice, is a good source of important antioxidants (vitamins $\mathrm{A}$ and $\mathrm{C}$ ). It can be consumed raw or cooked as a vegetable and can also be used commonly for making paste, pickle, and sauces (Doymaz and Pala 2002). This plant may be processed in a variety of ways, such as by pulpering and either by concentrating or by treating to paprika (ground pepper) which is a universally-known spice produced from red pepper fruits (Capsicum annum L.) to give color and flavor to various foods (Doymaz and Pala 2002; Bozkurt and Erkmen 2004; Jeevitha et al., 2013). Puree can be used directly in cooking or in food preparations for domestic purposes, for sauces and for other food production such as canning which provides an extended shelf-life while retaining its favorable qualities (Ismail and Revathi 2006). Red bell peppers (Capsicum annumm) were selected as the raw material, which is the second vegetable processed to paste after the tomato, which has high production rates in Turkey. In 2012, 748.422 tons of red peppers were processed to paste (Anon, 2013).

Microwave heating (MWH) is based on the transformation of alternating electromagnetic field energy into thermal energy by affecting the polar molecules of a material. In microwave heating, heat is generated directly into the material, leading to faster heating rates compared to conventional heating where heat is usually transferred from the surface to the interior (Baysal, 1994). Recent studies have shown that MWH also provides the transfer of functional components to the product (Canumir et al., 2002; Gerard and Roberts 2004).

In the industry, vegetables are blanched as a pretreatment in hot water or by steam which is effective on the yield and quality of the juice. But this thermal processing leads to an increase in energy and a decrease in the solids, nutrients and phytochemicals, and sensory attributes (texture, taste, flavor, and color) (Gerard and Roberts 2004; Jeevitha et al., 2013). Therefore, MWH as an alternative to $\mathrm{CH}$ was used in several studies to preserve the quality criteria such as texture, taste, flavor, and color (Dorantes-Alvarez et al., 2011; Ramesh et al., 2002; Jeevitha et al., 2013). Furthermore, it was stated that yield was improved after MWH (Gerard and Roberts 2004; Wang and Sastry 2002; Cendres et al., 2011; Cravotto et al., 2008; Leone et al., 2014).

Although microwave applications have been evaluated for some purposes in the food industry, to the best of our knowledge, no studies about optimizing the conditions for MWH of red pepper puree during the production using RSM has been reported in the literature. Therefore, the main objectives of this study were; (1) to determine the optimum process conditions for MWH application by RSM, and (2) to investigate the effects of $\mathrm{MWH}$ and $\mathrm{CH}$ applications on the yield and some quality characteristics of red pepper puree. In this way, the study of determining the optimization parameters for microwave heating provides new opportunities to enhance this technique in the production of red pepper puree to increase puree yield.

\section{MATERIALS AND METHODS Material}

Fresh red bell peppers (Capsicum annum L.) were purchased from a local market in Izmir, and then stored in a refrigerator at $+4^{\circ} \mathrm{C}$ and $92.4 \%$ humidity for a maximum of $24 \mathrm{~h}$ before processing to puree.

\section{Heating}

The raw materials were divided into two groups: Microwave heating $(\mathrm{MWH})$ and conventional heating $(\mathrm{CH})$. The production scheme for red pepper puree is given in Figure 1. The peppers were washed with water, the seeds and stems were removed, the peppers were then minced into small pieces and blended, and then processed into puree using a pulper. A total of $500 \pm 3 \mathrm{~g}$ of peppers was processed in pilot scale for each experiment of the response surface methodology (RSM) design. After optimization, red pepper purees were heated conventionally and also with a modified microwave oven. After heating, they were cooled to room temperature and the analyses were conducted. 


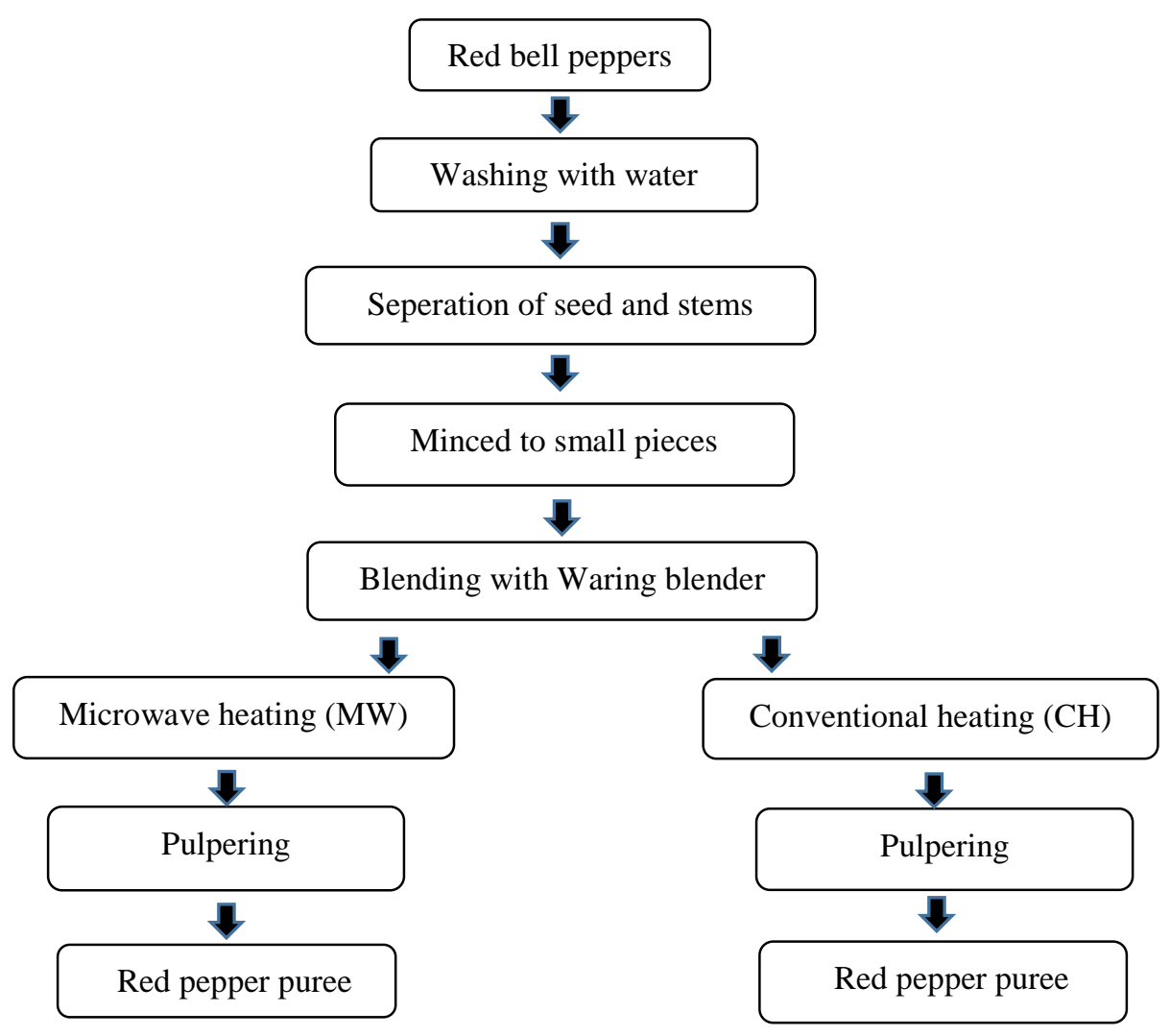

Figure1. Red pepper puree production scheme

\section{Microwave heating application}

A modified MW oven (Model Arcelik MW 595, Istanbul, Turkey) with $2450 \mathrm{MHz}$ operated at 540 to $900 \mathrm{~W}$ was used. The heating region of the MW oven contained a 3-m-long silicon hose and a peristaltic pump for controlling the flow (Watson Marlow [505U] Ltd., Falmouth, Cornwall, U.K.).
The inlet $\left(20^{\circ} \mathrm{C}\right)$ and outlet temperatures $\left(95^{\circ} \mathrm{C}\right)$ were measured using thermocouples. Flow rates between 5 to $15 \mathrm{rpm}$ were studied. Operating variables and ranges applied in the experimental design for the MWH application and the experimental design are shown in Table 1 and Table 2.

Table 1. Operating variables and ranges applied in the experimental design for MWH

\begin{tabular}{lcccc}
\hline Variables & Symbol & -1 & Level & +1 \\
\hline Microwave power $(\mathrm{W})$ & $\mathrm{x}_{1}$ & 540 & 720 & 900 \\
Flow rate $(\mathrm{rpm})$ & $\mathrm{x}_{2}$ & 5 & 10 & 15 \\
\hline
\end{tabular}

\section{Conventional heating application}

In this research, $\mathrm{CH}$ was carried out up to the outlet temperature of the MWH application. The samples were placed in glass jars of $200 \mathrm{~mL}$ and the jars were placed in a water bath (Daihan, DK7-1, Korea) at $95^{\circ} \mathrm{C}$. The jars were then removed when the temperature of the samples reached $95^{\circ} \mathrm{C}$. Heating was performed to $95^{\circ} \mathrm{C}$ same as the MWH application.

\section{Methods of analysis}

After processing, the effects of the red bell pepper puree MWH and $\mathrm{CH}$ treatments on the yield of the purees were calculated. The yield was calculated as follows: 


$$
\begin{aligned}
& \text { yield } \%=\frac{\text { weight of pepper before blender }(\mathrm{g})-\text { weight of pomace pulper }(\mathrm{g})}{\text { Weight of pepper before blender }(\mathrm{g})} * 100 \quad \text { Eq. (1) } \\
& \text { Increase in yield }(\%)=\frac{\text { yield of treatment group }(\%)-\text { yield of control }(\%)}{\text { yield of control }(\%)} * 100
\end{aligned}
$$

\section{Chemical and physical analysis}

Changes of the quality characteristics such as $\mathrm{pH}$, titratable acidity, total soluble solids, color, vitamin $C$, viscosity, and the pectin content of the samples were analyzed after the production of red bell pepper purees. Pectin content was investigated according to Anon (1968). The method is based on the extraction of pectin with ethanol after centrifugation $(4000 \mathrm{rpm}, 15 \mathrm{~min}$, $20^{\circ} \mathrm{C}$ ) (CFC free Universal Hettich Zentrifugen, Tuttlingen, Germany); the precipitated part was then treated with $5 \mathrm{~mL} \mathrm{NaOH}$ and completed with $100 \mathrm{~mL}$ deionized water. After filtration, the samples were prepared with $0.5 \mathrm{~mL}$ carbazol (Merck, Darmstadt, Germany) and $0.5 \mathrm{~mL}$ ethanol. Sulfuric acid (Merck, Darmstadt, Germany) (6 mL) was added to both samples, then they were placed in a water bath at $85^{\circ} \mathrm{C}$ for $5 \mathrm{~min}$. The absorbance values were taken at 525 $\mathrm{nm}$ with a Varian Cary 50 Scan (Sydney, Australia) spectrophotometer and the pectin content was calculated with the calibration curve that was made using the gallacturonic acid anhydrate standards (Sigma-Aldrich Corp., St. Louis). The ascorbic acid analysis was made by the spectrophometric (Varian Cary 50 Scan (Australia) spectophometer) method (Hış1 2004). The establishment of a standard curve: stabilizing solution (4\% oxalic acid (Merck, Darmstadt, Germany), dye solution (2,6-dichloroindophenol, $\mathrm{Na}$ salt), and ascorbic acid solution using a series of different concentrations were prepared and the absorbance at a wavelength of $518 \mathrm{~nm}$ against a standard showing the concentration of the vitamin $\mathrm{C}$ curve was obtained.

The viscosity of puree was measured by a Fungilab, Smart model viscosimeter (L3 spindle, $100 \mathrm{rpm}$ ). The total soluble matter ( ${ }^{\circ}$ Brix) of the puree was measured with a refractometer at $20^{\circ} \mathrm{C}$
(RFM 330; Bellingham Stanley Limited, Tunbridge Wells, Kent, U.K.) (AOAC 1995). The total titrable acidity was determined using a potentiometric titration of the acidity of the juice titrated up to a $\mathrm{pH} 8.1$ ( $\mathrm{pH}$ meter-W'TW InoLab) with a solution of $0.1 \mathrm{~N} \mathrm{NaOH}$. The results were expressed as $\mathrm{g} / 100 \mathrm{~mL}$ with reference to citric acid (AOAC 1995). The color $\left(L^{*}, a^{*}, b^{*}\right)$ values of the puree were measured with a Hunter Lab Colorflex colorimeter (Hunter Associates Laboratory, Reston, Va., U.S.A.).

\section{Statistical analysis}

RSM (Design Expert 7.0.0 STAT-EASE, 2005) was used for the optimization of the MWH application. The results were statistically analyzed with the Independent-Samples $T$ Test using the software SPSS 18 (SPSS Inc., Chicago, IL, U.S.A.) to evaluate the differences between treatments at a level of significance $P<0.05$. Each experiment was repeated 3 times.

\section{RESULTS AND DISCUSSION \\ Optimization}

The experimental value and analysis of variance (ANOVA) for responses are presented in Table 2 and Table 3. The statistical analysis indicated that the proposed model was adequate, possessing no significant lack of fit and with high $\mathrm{R}^{2}$ values for the response. ANOVA was conducted to determine the significant effects of process variables on each response and to fit the second order polynomial models to the experimental data.

In the MWH application, the effects of microwave power and flow rate on the yield of puree were investigated and the experimental design for the responses of yield and outlet temperature is shown in Table 2. 
Table 2. Experimental values of response variables for the central composite face centered design

\begin{tabular}{ccccc}
\hline Run & $\begin{array}{c}\text { Power of } \\
\text { microwave }(\mathrm{W})\end{array}$ & Flow rate (rpm) & Yield $(\%)$ & $\begin{array}{c}\text { Outlet Temperature } \\
\left({ }^{\circ} \mathrm{C}\right)\end{array}$ \\
\hline 1 & 720 & 10 & 70.86 & 85.0 \\
2 & 720 & 10 & 71.94 & 85.5 \\
3 & 900 & 5 & 71.78 & 95.7 \\
4 & 720 & 5 & 68.12 & 88.8 \\
5 & 900 & 10 & 72.60 & 88.9 \\
6 & 540 & 15 & 65.4 & 73.6 \\
7 & 720 & 10 & 71.35 & 86.5 \\
8 & 720 & 15 & 69.5 & 78.5 \\
9 & 720 & 10 & 72.54 & 87.5 \\
10 & 720 & 10 & 70.62 & 86.9 \\
11 & 540 & 10 & 67.47 & 75.4 \\
12 & 540 & 5 & 61.90 & 76.8 \\
13 & 900 & 15 & 68.36 & 82.9 \\
\hline
\end{tabular}

Table 3. ANOVA table showing the variables as a linear, quadratic, and interaction term on each response variable and coefficients for the prediction models

\begin{tabular}{|c|c|c|c|c|c|c|}
\hline \multirow[b]{2}{*}{ Source } & \multicolumn{3}{|c|}{ Yield $(\%)$} & \multicolumn{3}{|c|}{ Outlet Temperature $\left({ }^{\circ} \mathrm{C}\right)$} \\
\hline & Coefficient & $\begin{array}{l}\text { Sum of } \\
\text { squares }\end{array}$ & $\mathrm{p}$-value & Coefficient & $\begin{array}{l}\text { Sum of } \\
\text { squares }\end{array}$ & p-value \\
\hline Model & 71.53 & 114.52 & $<0.0001$ & 85.90 & 468.33 & $<0.0001$ \\
\hline $\mathrm{X}_{1}$ & 2.99 & 53.82 & $<0.0001$ & 6.95 & 289.81 & $<0.0001$ \\
\hline $\mathrm{x}_{2}$ & 0.24 & 0.36 & 0.4461 & -4.38 & 115.28 & $<0.0001$ \\
\hline $\mathrm{x}_{1} \mathrm{X}_{2}$ & -1.73 & 11.97 & 0.0022 & -2.40 & 23.04 & 0.0067 \\
\hline $\mathrm{x}_{1}^{2}$ & -1.68 & 7.79 & 0.0069 & -2.81 & 21.84 & 0.0077 \\
\hline $\mathrm{X}^{2}$ & -2.90 & 23.30 & 0.0003 & -1.31 & 4.75 & 0.1283 \\
\hline Residual & & 3.82 & & & 11.19 & \\
\hline Lack of fit & & 1.34 & 0.5887 & & 7.02 & 0.2251 \\
\hline Pure error & & 2.47 & & & 4.17 & \\
\hline Total & & 118.34 & & & 479.52 & \\
\hline $\mathrm{R}^{2}$ & & 0.9678 & & & 0.9767 & \\
\hline Adj- $R^{2}$ & & 0.9447 & & & 0.96 & \\
\hline Pred-R ${ }^{2}$ & & 0.8594 & & & 0.8743 & \\
\hline Std.Dev. & & 0.74 & & & 1.26 & \\
\hline PRESS & & 16.64 & & & 60.29 & \\
\hline CV & & 1.06 & & & 1.51 & \\
\hline
\end{tabular}

$\mathrm{x}_{1}$ Microwave power $(\mathrm{W}), \mathrm{x}_{2}$ Flow rate $(\mathrm{rpm})$

The Optimum point was determined by the desirability functions for max yield and $\max$ temperature:

$\%$ yield $=71.53+2.99 \mathrm{x}_{1}+0.24 \mathrm{x}_{2}-1.73 \mathrm{x}_{1} \mathrm{x}_{2}-1.68 \mathrm{x}_{1}{ }^{2}-2.90 \mathrm{x}_{2}{ }^{2}$ Eq. (3)

Outlet temperature $\left({ }^{\circ} \mathrm{C}\right)=85.90+6.95 \mathrm{x}_{1}-4.38 \mathrm{x}_{2}-2.40 \mathrm{x}_{1} \mathrm{x}_{2}-2.81 \mathrm{x}_{1}{ }^{2}-1.31 \mathrm{x}_{2}{ }^{2}$ 
Confirmation tests were made at $900 \mathrm{~W}$ and at 6 $\mathrm{rpm}$ processing conditions and the yield was found as $76.76 \%$ with the outlet temperature of $95.5^{\circ} \mathrm{C}$ in the $\mathrm{MWH}$ group. A $71.03 \%$ yield was found using $\mathrm{CH}$ with the same conditions of $95^{\circ} \mathrm{C}$ and 9 min processing time.

As shown in Figure 2, when the power of the microwave level increased, the yield also increased. Although the variables had a positive linear effect on the response (yield), the

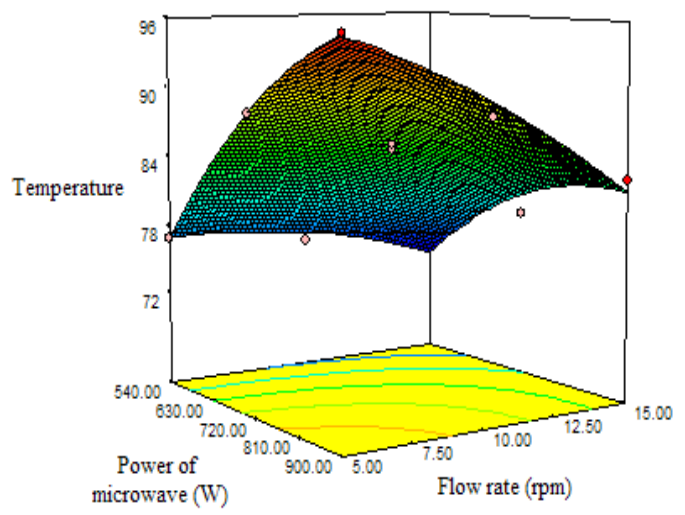

interaction effect of these variables had a negative effect on the yield.

The power level of the microwave had a positive effect, meaning that as the power increased the outlet temperature also increased. When the flow rate was lower, the outlet temperature became higher. Gerard and Roberts (2004) found that the juice yield was improved when the mash was heated.

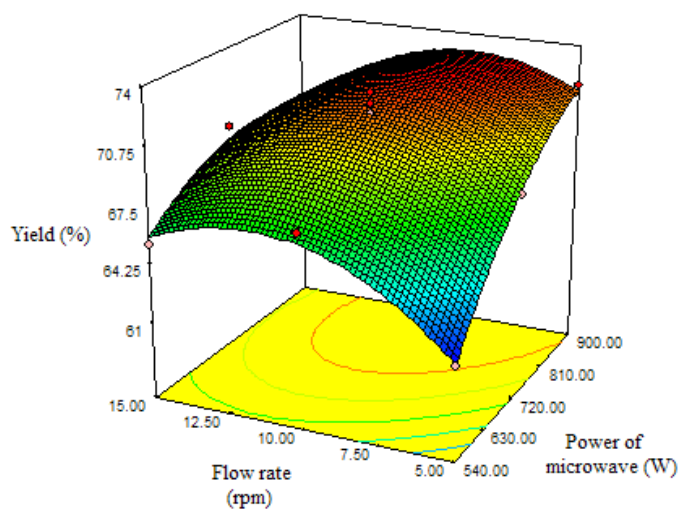

Figure 2. Response surface and contour plots for temperature and yield

Effect of electrical methods on the yield and quality characteristics of red bell pepper purees

Yields after treatments are shown in Table 4. In the MWH group, the yield was increased by $8.07 \%$ compared to the control, namely the $\mathrm{CH}$ group. This is an important ratio for industrial production. In a previous study, Rayman Ergün et al. (2015) found the yield as $76.3 \%$ after electroplasmolysis, after the combination of electroplasmolysis and MWH the yield increased by $7.56 \%$. In another study, Gerard and Roberts (2004) applied MWH to Fuji and McIntosh apple mashes. They compared the yield of juices obtained from the mashes which were heated by microwave and the unheated mashes. The juice yield enhanced significantly when the mash was heated before pressing $(P<0.05)$. Wang and Sastry (2002) carried out ohmic and MWH to investigate the electro-thermal effects on apple juice yield and then compared it to the unheated and preheated apple samples at 40 and $50^{\circ} \mathrm{C}$. They found that the apple juice yield was significantly improved by the ohmic and microwave pretreatments $(P<0.05)$. Cendres et al. (2011) developed a process for extraction of fruit juice by using microwave heating. MWH allowed rapid extraction of juice from fresh or frozen fruits (plum, apricot, and grape). They determined that MWH increased the yields. MWH increased the extraction of vegetable oils and olive oil compared to the conventional methods (Cravotto et al, 2008; Leone et al., 2014). Similar to our research, electroplasmolysis was applied to tomato puree and a $7.06 \%$ increase in electroplasmolysis when combined with steam heated samples was found by Yildız and Baysal (2007). In another study, different blanching methods before pulpering in red bell pepper paste production were investigated and the yield was determined as $51.40 \%$ after $\mathrm{CH}$ with steam for $5 \mathrm{~min}$ (Baysal et al., 1990). 
Table 4. Quality characteristics of pepper puree

\begin{tabular}{cccccccc}
\hline Groups & Yield $(\%)$ & $\mathrm{pH}$ & TSS $\left({ }^{\circ} \mathrm{Bx}\right)$ & $\begin{array}{c}\text { Acidity } \\
(\%)\end{array}$ & $\begin{array}{c}\text { Pectin content } \\
(\mathrm{GA}-\mathrm{AH}, \\
\mathrm{mg} / \mathrm{L})\end{array}$ & $\begin{array}{c}\text { Vit C } \\
(\mathrm{mg} / 100 \\
\mathrm{ml})\end{array}$ & $\begin{array}{c}\text { Viscosity } \\
(\text { Pa.s })\end{array}$ \\
\hline $\mathrm{MWH}$ & $76.76 \pm 0.30^{\mathrm{a}}$ & $4.92 \pm 0.01^{\mathrm{a}}$ & $9.87 \pm 0.06^{\mathrm{a}}$ & $3.43 \pm 0.13^{\mathrm{a}}$ & $1012.33 \pm 12.67 \mathrm{a}$ & $4.63 \pm 0.14^{\mathrm{a}}$ & $0.67 \pm 0.03^{\mathrm{a}}$ \\
$\mathrm{CH}$ & $71.03 \pm 0.40^{\mathrm{b}}$ & $4.94 \pm 0.01^{\mathrm{b}}$ & $9.77 \pm 0.06^{\mathrm{a}}$ & $3.16 \pm 0.13^{\mathrm{a}}$ & $859.72 \pm 25.28^{\mathrm{b}}$ & $3.91 \pm 0.19^{\mathrm{b}}$ & $0.33 \pm 0.01^{\mathrm{b}}$ \\
\hline a to b Different letters within columns are significantly different $(P<0.05)$
\end{tabular}

Wang and Sastry (2002) reported that MWH can generate an enhancement in mass transport because of electroporation of the cell membrane and thermal denaturation of membranes. Therefore, the yield of red bell pepper puree was increased compared to $\mathrm{CH}$.

The $\mathrm{pH}$ values of the samples ranged between 4.92 - 4.94. The $\mathrm{pH}$ values of MWH were found to be less than the $\mathrm{CH}$ treatments $(P<0.05)$. The values were found similar to those in other studies such as Shaha et al. (2013), who determined that the $\mathrm{pH}$ value of red peppers varied between 5.43 - 5.73. Ahmet et al. (2002a) found the $\mathrm{pH}$ value of green chili pepper puree as 5.08. Another researcher who studied with Habanero red chili pepper which is grown in Yucatan found the $\mathrm{pH}$ values as 5.2 - 5.4 (Pino et al., 2007).

The total soluble matter ( ${ }^{\circ}$ Brix) values varied between 9.77-9.87. Castro et al. (2008) reported

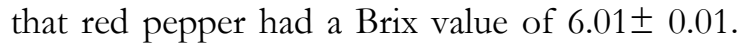
Pino et al. (2007) found that the total soluble solids of chili pepper varied between 6.4-7.7. After treatments the soluble solid content transferred to the puree. There was no significant difference between the ${ }^{\circ}$ Brix values of the different heat applied groups $(P>0.05)$. Previous studies found the ${ }^{\circ}$ Brix value of green chili puree as 4.8 (Ahmed et al., 2002a). In addition, same researchers determined that red chili puree has a ${ }^{\circ}$ Brix value of 11.6 (Ahmed et al., 2002b).

The acidity value after heat treatments was found as $3.16-3.43 \%$. There were no significant differences between the $\mathrm{CH}$ and MWH groups $(P$ $>0.05$ ). Castro et al. (2008) who investigated thermal blanching on red bell pepper found the acidity as $2.61 \pm 0.09 \mathrm{~g} / 100 \mathrm{ml}$.

The pectin content of the MWH group was found as $1012.33 \pm 12.67(\mathrm{GA}-\mathrm{AH}, \mathrm{mg} / \mathrm{L})$ which was higher than the $\mathrm{CH}$ group. In the previous study, pectin content was found as $498.75 \pm 18.45 \mathrm{after}$ electroplasmolysis and MWH combination, in $\mathrm{CH}$ group this content was found as $477.56 \pm$ 8.50 (GA-AH, mg/L) (Ergün et al, 2015). The difference between the pectin contents was due to the properties of raw material and seasonal changes. Baysal et al. (1990) found the pectin values of red bell pepper puree as $0.379 \mathrm{~g} / 100 \mathrm{~g}$ and after water blanching as $0.405 \mathrm{~g} / 100 \mathrm{~g}$. Christiaens et al. (2012) determined that the water soluble pectin content $(\%)$ decreased when compared to the raw material, after high temperature blanching of broccoli puree at $95^{\circ} \mathrm{C}$ for $5 \mathrm{~min}$ and low temperature blanching at $60^{\circ} \mathrm{C}$ for $40 \mathrm{~min}$. Ismail and Revathi et al. (2006) determined the alcohol insoluble pectin as $11 \mathrm{~g}$ pectin/100 g solid matter. The viscosity values changed according to the pectin content. In the samples which were treated by $\mathrm{MWH}$, the viscosity was higher than the other group.

The vitamin $\mathrm{C}$ content in the MWH group was found as $4.63 \pm 0.14$ and in the $\mathrm{CH}$ group as $3.91 \pm 0.19 \mathrm{mg} / 100 \mathrm{ml}$. Vitamin $\mathrm{C}$ which is degradable with the effect of heat decreased significantly after $\mathrm{MWH}$ and after conventional heating at $95^{\circ} \mathrm{C}$. In a study of Rayman Ergün et al. (2015) in the EP+MWH group vitamin C was found as $16.64 \mathrm{mg} / 100 \mathrm{ml}$ Vitamin C content differs with the harvest season so the results were different from each other. Similar to our study, Chuah et al. (2008) who studied different heating treatments such as MWH, cooking, stir frying, and boiling in water, indicated that there is a significant decrease in Vitamin C content after treatments. They also emphasized that the best method for protecting the vitamin $\mathrm{C}$ was MWH heating at $95^{\circ} \mathrm{C}$ for $5 \mathrm{~min}$. In agreement with our results, Ramesh et al. (2002) who researched the effects of microwave blanching at $95^{\circ} \mathrm{C}$ for spinach, carrot, and bell peppers, revealed that the 
losses in Vitamin C content decreased by microwave by $8.5 \%$ for bell peppers, $18 \%$ for spinach, and by $33.5 \%$ for carrot. Jeevitha et al. (2013) studied with red bell peppers and determined the blanching effects. Retention of ascorbic acid was detected. The losses were higher with water and steam blanching compared to $\mathrm{MWH}$ and infrared blanching.

The color values were also compared after heat treatments as shown in Table 5. The color values and changes were parallel to the previous studies. Lightness was better in the MWH group. The Hunter $\mathrm{L}^{*}$ value in the fresh sweet red pepper was found as 28.02 by Eissa et al. (2007). a* and b* values were indicated as 35.39 and 19.62 in the same study. Reyes de Corcuera et al. (2004) stated that blanching affects the color directly and indirectly, for example as degradation of pigments such as chlorophyll. Mexican bell peppers were boiled at $96^{\circ} \mathrm{C}$ and the $\mathrm{L}, \mathrm{a}$, and $\mathrm{b}$ values were measured for purees. The values were $43.5 \pm 0.5$, 44.4 \pm 0.5, and 37.6 \pm 1.5 , respectively (OrnelasPaz et al., 2010). In a different study, the color parameters $(\mathrm{L}, \mathrm{a}, \mathrm{b})$ of fresh red chili peppers were found respectively as 29.7, 37.1, and 18.1 (Ahmed et al., 2002b). They applied acidic and thermal process, detected a significant reduction in the color values $\mathrm{L}$, a, b (8.65, 15.78, and 8.16). Ismail and Revathi (2006) determined that the $L$ values changed between 41.10 - 40.80, the a values between 45.06 - 44.86, and the $\mathrm{b}$ value between $60.17-58.84$ of the boiled red bell pepper puree at $90^{\circ} \mathrm{C}$ for $5-20 \mathrm{~min}$.

Table 5. Color properties of pepper puree

\begin{tabular}{lccc}
\hline Groups & $\mathrm{L}^{*}$ & $\mathrm{a}^{*}$ & $\mathrm{~b}^{*}$ \\
\hline MWH & $30.20 \pm 0.02^{\mathrm{a}}$ & $44.66 \pm 0.05^{\mathrm{a}}$ & $16.89 \pm 0.02^{\mathrm{a}}$ \\
$\mathrm{CH}$ & $29.36 \pm 0.03^{\mathrm{b}}$ & $43.99 \pm 0.06^{\mathrm{b}}$ & $16.59 \pm 0.05^{\mathrm{b}}$ \\
\hline a to bDiffent
\end{tabular}

a to bDifferent letters within columns are significantly different $(P<0.05)$

\section{CONCLUSION}

In this study, the yields of pepper puree were calculated as $76.76 \%$ for MWH and $71.03 \%$ for $\mathrm{CH}$ groups. In the $\mathrm{MWH}$ group the yield improved by $8.07 \%$ compared to the $\mathrm{CH}$ group. The difference between the groups via the $\mathrm{pH}$, acidity, and TSS ( ${ }^{\circ}$ Brix) were found statistically insignificant. Pectin and the viscosity of red pepper puree were detected higher after the MWH application compared to $\mathrm{CH}$. MWH application preserved vitamin $\mathrm{C}$ better which was determined as $4.63 \pm 0.14 \mathrm{mg} / 100 \mathrm{ml}$. The color values were protected better after MWH. As a result, MWH increased the yield and improved the quality of the red pepper puree.

\section{REFERENCES}

Ahmed, J., Shivhare, U.S., Debnath, S. (2002a). Colour degradation and rheology of green chilli puree during thermal processing. Int. J. Food Sci.Technol. 37, 57-63.

Ahmed, J., Shivhare, U.S., Ramaswamy, H.S. (2002b). A Fraction Conversion Kinetic Model for Thermal Degradation of Color in Red Chilli Puree and Paste. Lebensm.-Wiss. Technol. 35, 497503.
Anon (1968). IFJU, Methods Of Analyses. Metod26. International Federation of Fruit Juice Producers, 10, Rue De Liege, Paris, France.

AOAC (1995). In: Official Methods of Analysis of AOAC International, 16th edn. Arlington, VA: Association of Official Analytical Chemists.

Anon. (2013). Turkey Statistical Institute, Turkey's Statistical Yearbook, Ankara.

Baysal, T. (1994). The Effects of microwave and conventional blanching methods on the quality of selected vegetables. PhD Thesis, p.160, Ege University Institute of Natural and Applied Science, Department of Food Engineering, Izmir, Turkey.

Baysal, T., Güres, H., Yurdagel, Ü. (1990). Biber salçası yapımında palper öncesi farklı haşlama yöntem ve sürelerinin palper verimi ve şıra kalitesine etkileri. GIDA. 15(2), 73-78.

Bozkurt, H., Erkmen, O. (2004). Effects of production techniques on the quality of hot pepper paste. J. Food Eng. 64, 173-178. 
Canumir, J.A., Celis, J.E., De Brujin, J., Vidal, L.V. (2002). Pasteurization of apple juice by using microwaves. Food Sci. Technol. 35, 389-392.

Castro, S.M., Saraiva, J.A., Lopes-Da-Silva, J.A., Delgadillo, I., Loey, A.V., Smout, C. Hendrickx, M. (2008). Effect of thermal blanching and of high pressure treatments on sweet green and red bell pepper fruits (Capsicum annuum L.). Food Chem. 107, 1436-1449.

Cendres, A., Chemat, F., Jean-François, M., Renard, C.M.G.C., (2011). An innovative process for extraction of fruit juice using microwave heating. LWT-Food Sci. Technol. 44, 1035-1041.

Christiaens, S., Mbong, V.B., Buggenhout, S.V., David, C.C., Hofkens, J., Loey, A.M.V., Hendrickx, M.E. (2012). Influence of processing on the pectin structure-function relationship in broccoli puree. Innov. Food Sci. Emerg. Technol. 15, 57-65.

Chuah, A.M., Lee, Y.C., Yamaguchi, T., Takamura, H., Yin, L.J., Matoba, T. (2008). Effect of cooking on the antioxidant properties of coloured peppers. Food Chem. 111, 20-28.

Cravotto, G., Boffa, L., Mantegna, S., Perego, P., Avogadro, M., Cintas, P. (2008). Improved extraction of vegetable oils under high-intensity ultrasound and/or microwaves. Ultrason. Sonochem. 15, 898-902.

Dorantes-Alvarez, L., Jaramillo-Flores, E., González, K., Martinez, R., Parada, L. (2011). Blanching peppers using microwaves. Procedia Food Sci. 1, $178-183$.

Doymaz, İ., Pala, M. (2002). Hot-air drying characteristics of red pepper. J. Food Eng. 55, 331335.

Eissa, H.A., Mostafa, B.E., Hussein, A.S. (2007). Capsaicin Content and Quality Characteristics in Different Local Pepper Varieties (Capsicum Annum) and Acid-Brine Pasteurized Puree. J. Food Technol. 5, 246-255.

Gerard, K.A., Roberts, J.S. (2004). Microwave heating of apple mash to improve juice yield and quality. Lebensm.-Wiss. Technol. 37, 551-557.
Hışıl, Y. (2004). Enstrümental Gıda Analizleri Laboratuar Deneyleri. Ege Üni. Müh. Fak. Ders Kitaplanı Yayın No: 45. İzmir.

Ismail, N., Revathi, R. (2006). Studies on the effects of blanching time, evaporation time, temperature and hydrocolloid on physical properties of chili (Capsicum annuum var kulai) puree. LWT-Food Sci. Technol. 39, 91-97.

Jeevitha, G.C. Hebbar Umesh, H., Raghavarao, K.S.M.S. (2013). Electromagnetic RadiationBased Dry Blanching of Red Bell Peppers: A Comparative Study. J. Food Process. Eng.36, 663674.

Leone, A., Tamborrino, A., Romaniello, R., Zagaria, R., Sabella, E. (2014). Specification and implementation of a continuous microwaveassisted system for paste malaxation in an olive oil extraction plant. Biosystems Eng. 125, 24-35.

Ornelas-Paz, J.D.J., Martínez-Burrola, J.M., RuizCruz, S., Santana-Rodríguez, V., Ibarra-Junquera, V., Olivas, G.I., Pérez-Martínez, J.D. (2010). Effect of cooking on the capsaicinoids and phenolics contents of Mexican peppers. Food Chem. 119, 1619-1625.

Pino, J., Gonzalez, M., Ceballos, L., Centurionyah, A., Trujilloaguirre, J., Latourneriemoreno, L., Sauriduch, E. (2007). Characterization of total capsaicinoids, colour and volatile compounds of Habanero chilli pepper (Capsicum chinense Jack.) cultivars grown in Yucatan. Food Chem. 104, 1682-1686.

Ramesh, M.N., Wolf, W., Tevını, D., Bognár. A. (2002). Microwave blanching of vegetables. J. Food Sci. 67 (1), 390-398.

Rayman Ergün, A., Bozkir, H., Taştan, Ö., Baysal, T. (2015). Effects of Electrical Pretreatments on the Yield and Quality Characteristics of Red Bell Pepper Puree. J. Food Qual, 38: 396-404.

Reyes De Corcuera, J.J., Cavaleri, R.P., Powers, J.R. (2004). Blanching of foods. In: Encyclopedia of Agricultural, Food, and Biological Engineering (edited by D.R.Heldman). Pp. 1-5. New York: Marcel Dekker, Inc.

Shaha, R.K., Rahman, S., Asrul, A. (2013). Bioactive compounds in chilli peppers (Capsicum 
annuum L.) at various ripening (green, yellow and red) stages. Ann. Biol. Res. 4 (8), 27-34.

Wang, W.C., Sastry, S.K. (2002). Effects of moderate electrothermal treatments on juice yield from cellular tissue. Innov. Food Sci. Emerg. Technol. 3, 371-377.
Yildız, H., Baysal, T. (2007). Color and Lycopene content of tomato puree affected by electroplasmolysis. Int. J. Food Prop. 10, 489-495. 